FIU Law Review

Volume 13

Number 2 Decanal Issue

Article 9

Fall 2018

\title{
The Delusion of Amateurism in College Sports: Why Scholarship Student Athletes Are Destined to Be Considered "Employees" under the NLRA
}

Michael Pego

J.D., 2018, Florida International University College of Law

Follow this and additional works at: https://ecollections.law.fiu.edu/lawreview

Part of the Labor and Employment Law Commons

Online ISSN: 2643-7759

Recommended Citation

Michael Pego, The Delusion of Amateurism in College Sports: Why Scholarship Student Athletes Are Destined to Be Considered "Employees" under the NLRA, 13 FIU L. Rev. 277 (2018).

DOI: https://dx.doi.org/10.25148/lawrev.13.2.9

This Comment is brought to you for free and open access by eCollections. It has been accepted for inclusion in FIU Law Review by an authorized editor of eCollections. For more information, please contact lisdavis@fiu.edu. 


\title{
The Delusion of Amateurism in College SPORTs: Why SChOlarship Student ATHLETES ARE DESTINED TO BE CONSIDERED "EMPLOYEES" UNDER THE NLRA
}

\author{
Michael Pego*
}

"I tend to be more worried about college players than NFL players in the sense that the NFL players have a union ... and most of them are well-compensated for the violence they do to their bodies. You read some of these stories about college players who undergo some of these same problems with concussions and so forth and then have nothing to fall back on. That's something that I'd like to see the NCAA think about."

\section{-President Barack Obama}

"Maintaining amateurism is crucial to preserving an academic environment in which acquiring a quality education is the first priority. In the collegiate model of sports, the young men and women competing on the field or court are students first, athletes second."

$$
\text { -NCAA }
$$

"For me, it is far better to grasp the Universe as it really is than to persist in delusion, however satisfying and reassuring." 3

-Carl Sagan

I. Introduction

II. An Overview of the NLRB, the Northwestern Cases, and

Decisions Involving Scholarship Student Athletes and

Graduate Assistants

A. The NLRB Framework

\footnotetext{
* J.D., 2018, Florida International University College of Law.

1 Ranklin Foer \& Chris Hughes, Barack Obama Is Not Pleased, NeW RePuBliC (Jan. 27, 2013), https://newrepublic.com/article/112190/obama-interview-2013-sit-down-president.

2 Amateurism, NCAA, http://www.ncaa.org/amateurism (last visited Oct. 30, 2016).

3 Carl Sagan, The Demon-Haunted World: Science as a Candle in the Dark 12 (Ballantine Books reprt. ed. 1997).
} 
1. Establishment, Purpose, Organization, and Process ..........282

2. "Employee" under the NLRA ............................................284

B. Northwestern University Rulings on Scholarship Athletes .....288

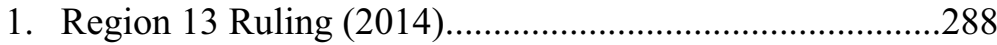

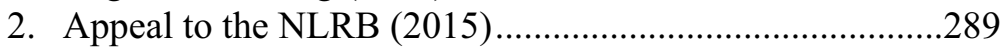

C. NLRB Decisions Regarding Student Assistants ......................290

1. Establishing Precedent: Stanford (1974)............................290

2. A Departure from Stanford: NLRB Rules that Graduate Assistants Are Employees in New York University (2000) ............................................291

3. Reversion to Stanford: Brown University (2004) ..............292

4. The Current Standard: Columbia University (2016)..........292

III. Analysis of the Northwestern University (Regional Decision) and Northwestern University Decisions..........................................293

IV. Impact of the Ruling in Columbia University on a Renewed Northwestern University Challenge .................................................298

A. Comparing Scholarship Student Athletes with the Student Assistants

B. Issues of a Ruling that Scholarship Student Athletes Are Employees under the NLRA and Possible Solutions. 300

C. Why an Affirmative NLRB Decision Would Promote Stability in the NCAA. 303

V. An Analysis of Recent Developments .........................................306

A. Northwestern's Football Handbook ...........................................307

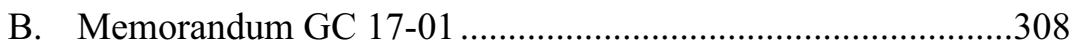

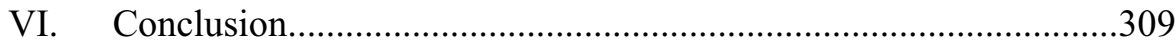

\section{INTRODUCTION}

A collegiate athletic competition played between a perennial powerhouse program and a program of a lesser stature is often referred to in the sports media industry as a "David versus Goliath" matchup. ${ }^{4}$ This is of

4 See, e.g., Rafi Alim, Maya Reese \& Vijay Vemu, March Madness: Will David or Goliath Win the NCAA Tournament?, SUN SENTINEL (Mar. 13, 2015, 2:48 PM), http://www.sunsentinel.com/features/south-florida-parenting/stages/sfp-march-madness-will-david-or-goliath-winthe-ncaa-tournament-20150313-story.html; Anthony Chiusano, David vs. Goliath Retold: Looking Back at Boise State's 2007 Fiesta Bowl Upset Over Oklahoma, NCAA (Jan. 1, 2017), http://www.ncaa.com/news/football/article/2017-01-01/david-vs-goliath-retold-looking-back-boisestates-2007-fiesta-bowl; William C. Rhoden, When David Meets Goliath on the Hardwood, N.Y. TiMES (Apr. 2, 2011), http://www.nytimes.com/2011/04/03/sports/ncaabasketball/03rhoden.html; Jake Simpson, 'David vs. Goliath' in NCAA Final, ATLANTIC (Apr. 5, 2010), http://www.theatlantic.com/entertainment/archive/2010/04/david-vs-goliath-in-ncaa-final/341108/. 
course a reference to the fabled biblical tale of when David challenged and successfully defeated the behemoth known as Goliath of Gath. ${ }^{5}$ In contrast to the outcome of the biblical tale, typically these sports matchups result in the more feeble opponent suffering an anticipated loss at the hands of its powerhouse of an opponent. Although the title of "David versus Goliath" is usually bestowed to the games played on the court or field, it is also an appropriate tagline for the challenge a group of scholarship football players at Northwestern University ("Northwestern" or "University") faced in the courtroom when they took on the behemoth known as the National Collegiate Athletic Association ("NCAA") and its nearly one billion dollars in annual revenues. ${ }^{6}$

The attempt to extend employee status to scholarship athletes first began in 2014, when a former University of California, Los Angeles, linebacker and the director of the United Steelworkers Political Action Committee delivered union cards signed by nearly seventy percent ${ }^{7}$ of the Northwestern football team - surpassing the National Labor Relations Board ("NLRB" or "Board") requirement of thirty percent ${ }^{8}$ - to the NLRB's Chicago-based office. ${ }^{9}$ On March 26, 2014, a regional board of the NLRB briefly gave us a "David versus Goliath" outcome when it ruled in favor of the student athletes, finding that the Northwestern scholarship student athletes were "employees" under the National Labor Relations Act ("NLRA" or "Act") and could proceed to form a union and begin the process of collectively bargaining with the University. ${ }^{10}$ However, this victory was short lived. On appeal, the NLRB effectively ended the scholarship student athletes' attempt to unionize for the time being. ${ }^{11}$ On August 17, 2015, the NLRB declined to extend its

51 Samuel 17:33.

6 The NCAA's financial statements for the 2014 fiscal year reported a total revenue of approximately $\$ 989$ million. This figure resulted in a surplus of approximately $\$ 80.5$ million-up nearly $\$ 20$ million from the surplus in 2013. Steve Berkowitz, NCAA Nearly Topped \$1 Billion in Revenue in 2014, USA TODAY (Mar. $11, \quad 2015, \quad 4: 59 \quad$ PM), http://www.usatoday.com/story/sports/college/2015/03/11/ncaa-financial-statement-2014-1-billionrevenue/70161386/.

7 The Times Editorial Board, Why Can't College Athletes Unionize?, L.A. TIMES (Aug. 26, 2015, 5:00 AM), http://www.latimes.com/opinion/editorials/la-ed-ncaa-20150826-story.html.

8 Conduct Elections, NAT'L LABOR RELATIONS BD., https://www.nlrb.gov/what-we-do/conductelections (last visited Nov. 6, 2016).

9 Joe Nocera \& Ben Strauss, Fate of The Union: How Northwestern Football Union Nearly Came to $B e$, SPORTS ILlUSTRATED (Feb. 24, 2016), http://www.si.com/collegefootball/2016/02/24/northwestern-union-case-book-indentured.

10 Nw. Univ., Case No. 13-RC-121359, at *2 (2014).

11 See Board Unanimously Decides to Decline Jurisdiction in Northwestern Case, NAT'L LABOR RELATIONS BD. (Aug. 17, 2015), https://www.nlrb.gov/news-outreach/news-story/board-unanimouslydecides-decline-jurisdiction-northwestern-case [hereinafter Board Declines Jurisdiction]. 
jurisdiction in a case that would have ruled that scholarship student athletes are "employees" under the Act. ${ }^{12}$

Almost one year after its "punt,"13 the NLRB issued a decision that could potentially breathe life into the seemingly dead-end ${ }^{14}$ movement to unionize scholarship student athletes. The case was Columbia University and there, the NLRB was tasked with examining the issue of whether student assistants were "employees" under the NLRA. ${ }^{15}$ In Columbia University, the Board held that the student assistants were "employees" under the Act and thus were an appropriate collective bargaining unit. ${ }^{16}$ This decision had two effects: (1) it overruled nearly twelve years of NLRB precedent; ${ }^{17}$ and (2) it ignited a discussion of the differences, or lack thereof, between student assistants and scholarship student athletes. ${ }^{18}$

12 Id.; Tom Farrey, Northwestern Players Denied Request to Form First Union for Athletes, ESPN (Aug. 17, 2015), http://www.espn.com/college-football/story/_id/13455477/nlrb-says-northwesternplayers-cannot-unionize (analyzing the ramifications of the NLRB's decision).

13 Many media outlets have colorfully categorized the NLRB's non-decision as a "punt." See, e.g., Roger I. Abrams, Labor Board Punts on Northwestern Football Case, HuFFINGTON Post (Aug. 20, 2015, 12:06 PM), http://www.huffingtonpost.com/roger-i-abrams/labor-board-punts-on-nort_b_8016084.html; Philip Miles, NLRB Punts on Northwestern Football Union, LEXISNEXIS (Aug. 18, 2015, 8:57 AM), https://www.lexisnexis.com/legalnewsroom/labor-employment/b/labor-employment-topblogs/archive/2015/08/18/nlrb-punts-on-northwestern-football-union.aspx; Daniel Pasternak, NLRB Punts In Northwestern University Football Case, Declines To Decide Whether Scholarship Athletes at Private Universities Can Join A Union, EMP L. WorldVIEW (Aug. 17, 2015), http://www.employmentlawworldview.com/nlrb-punts-in-northwestern-university-football-casedeclines-to-decide-whether-scholarship-athletes-at-private-universities-can-join-a-union/. The term "punt" is used in football when one team, after failing to advance their position enough to gain a "first down" or place themselves in position to score, decides to kick the ball to the other team, so the other team may have possession of the ball. The term "punt" therefore has the connotation of passing on the responsibility of something to another.

14 See Zachary Zagger, College Athlete Employee Claims a Dead End Post-Penn Suit, LAw360 (Feb. 19, 2016, 10:15 PM), http://www.law360.com/articles/761312/college-athlete-employee-claims-adead-end-post-penn-suit.

15 Trs. of Columbia Univ., 364 N.L.R.B. 90, at*1 (2016).

16 Id. at *2 (holding that "student assistants who have a common-law employment relationship with their university are statutory employees under the Act. We will apply that standard to student assistants, including assistants engaged in research funded by external grants.”).

17 See id. at $* 1$.

18 See Lawrence E. Dubé, Will College Athletes' Labor Rights Follow Grad Student Ruling?, BLOOMBERG BNA (Sept. 23, 2016), https://www.bna.com/college-athletes-labor-n57982077527/; Marc Edelman, NLRB Decision to Unionize Columbia Student Workers May Help College Athletes' Union

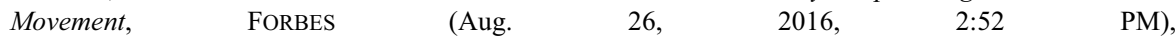
http://www.forbes.com/sites/marcedelman/2016/08/26/nlrb-decision-to-unionize-columbia-studentworkers-may-help-college-athletes-union-movement/; Jared Keller, Graduate Assistants are Officially University Employees. Why Aren't Athletes?, PAC. STANDARD (Aug. 24, 2016), https://psmag.com/graduate-assistants-are-officially-university-employees-why-arent-athletes8834ed0d8d5f; Josh Scharff, NLRB Says Graduate Student Assistants are Employees: Columbia University Reverses Brown University, PEER, GAN \& GISLER LLP (Aug. 26, 2016), http://peerganlaw.com/nlrb-says-graduate-student-assistants-are-employees-columbia-universityreverses-brown-university/. 
Given the NLRB's recent ruling in Columbia University, the Board has placed itself in a position to potentially declare that scholarship student athletes are "employees" under the NLRA because the group fits into the framework established in Columbia University, due to the similarities between scholarship student athletes and student assistants, and because scholarship student athletes easily satisfy the common law control test for employment. In response to the NLRB's concern over the implications of a possible disruption of labor stability with such a ruling, ${ }^{19}$ it has been hypothesized that a ruling in favor of scholarship student athletes would be more manageable for the NLRB if a collective challenge were to be brought from an athletic conference with a large amount of private universities. ${ }^{20}$ Additionally, such a ruling could arguably promote labor stability because of what the NCAA industry has become and because a ruling could potentially reduce the likelihood of programs providing impermissible benefits to its students and being subject to sanctions.

Although this Comment will not explore all the potential outcomes of a ruling in favor of a scholarship student athlete union, including the potential for a revenue-sharing business model for the NCAA and the players, ${ }^{21}$ this Comment will examine the case for the unionization of scholarship student athletes. However, it is imperative to note the magnitude of what is at stake for both parties in the event of such a ruling, including such implications as: potential discrimination claims with the Equal Employment Opportunity Commission if a student athlete were to lose his or her starting job on the team; whether a student athlete would be rewarded his or her starting position back under the Family and Medical Leave Act upon his or her return if it was lost only because of injury; and whether a university would be obligated to provide its student athletes with health insurance, as mandated by the Patient Protection and Affordable Care Act. ${ }^{22}$ Also, some have hypothesized that a

19 Board Declines Jurisdiction, supra note 11. Specifically, the Board held that there has never been an instance where they have asserted

$[\mathrm{J}]$ urisdiction in a case involving scholarship football players or similarly situated individuals, and for the reasons stated above, ... decline[d] to do so in this case. Processing a petition for the scholarship players at this single institution under the circumstances presented here would not promote stability in labor relations.

Id. (emphasis added).

20 See Marc Edelman, The Future of College Athlete Players Unions: Lessons Learned from Northwestern University, and Potential Next Steps in the College Athletes Rights Movement, 38 CARDOZO L. REV. 1627, 1642 (2017).

21 See Antonio Gonzalez, College Athletes Union Could Put Billions at Stake, AssociATED PRESS (Apr. 6, 2014, 3:09 PM), http://collegefootball.ap.org/article/college-athletes-union-could-put-billionsstake.

22 See Lori K. Mans \& J. Evan Gibbs, Student Athletes As Employees?, 89 FLA. B.J. 34 (2015); see also Labor and Employment Alert: NLRB Regional Director Holds Northwestern University Football Players Are Employees, And Can Unionize, VORYs (Mar. 27, 2014), http://www.vorys.com/publications- 
union would entitle scholarship student athletes to vital due process protections, including requiring both notice and a hearing prior to a student athlete being punished, and pension plans. ${ }^{23}$

This Comment will review the NLRB's decision in the Northwestern University case and how its recent ruling in Columbia University has opened the door for a different outcome in a future challenge in the following manner: (1) a primer of the framework of the NLRB, including an analysis of who is an "employee" under the NLRA; (2) an overview of the Region 13 decision to declare scholarship student athletes employees and its subsequent appeal, and of NLRB decisions regarding student assistants; (3) a critique and analysis of the Northwestern cases; (4) an analysis of how Columbia University has opened the door for a renewed, collective challenge of the NLRB's decision in Northwestern University, including an examination of the differences between the groups and the potential impact on collegiate sports as a whole; and finally (5) an analysis of recent developments regarding student athletes at Northwestern, specifically, two memoranda released in the latter part of 2016 and early 2017, respectively.

\section{AN OVERVIEW OF THE NLRB, THE NORTHWESTERN CASES, AND DECISIONS INVOLVING SCHOLARSHIP STUDENT ATHLetes AND GraduAte Assistants}

\section{A. The NLRB Framework}

\section{Establishment, Purpose, Organization, and Process}

After a series of failed attempts to create an effective labor enforcement organization, ${ }^{24}$ the current version of the NLRB was established by the

1225.html; David J. Santeusanio, NLRB Decision on Student-Athlete Unionization a Win for Colleges, But Title IX Still in Play, Holland \& KNIGHT (Aug. 26, 2015), https://www.hklaw.com/Publications/NLRB-Decision-on-Student-Athlete-Unionization-a-Win-forColleges-But-Title-IX-Still-in-Play-08-26-2015/.

23 Marc Edelman, Should College Athletes Be Allowed to Unionize?, WALl STREET J. (Sept. 15, 2015, 10:01 PM), http://www.wsj.com/articles/should-college-athletes-be-allowed-to-unionize1442368889. Edelman, almost in a clairvoyant fashion, also noted that a union would provide the student athletes with the "freedom to voice their opinions on social media without their college's interference." The clairvoyance of the assertion came to fruition when Northwestern modified its Football Handbook, removing several key prohibitions on student athletes' social media usage. See BARRY J. KEARNY, NAT'L LABOR RElations Bd., OfFICE of THE GENERAL COUNSEl, AdVICE MEMORANDUM: NORTHWESTERN UNIVERSITY CASE 13-CA-157467 (Sept. 22, 2016), http://www.constangy.net/nr_images/els-nlrb-advicememorandum-9-22-16.pdf.

24 The first iteration of what we now know as the NLRB was the National Labor Board, created in 1933 by President Roosevelt to enforce certain provisions of the National Industrial Recovery Act ("NIRA"). It was disbanded roughly one year after its creation primarily due to its ineffectiveness. See 
NLRA in $1935 .{ }^{25}$ The NLRA, which is only applicable to private employment, ${ }^{26}$ was enacted to "protect the rights of employees and employers, to encourage collective bargaining, and to curtail certain private sector labor and management practices, which can harm the general welfare of workers, businesses and the U.S. economy." ${ }^{27}$ The Act grants the following rights to employees: (1) organize a potential union for the purposes of negotiating with an employee's employer to discuss and negotiate integral issues such as compensation, hours, and other various employment terms and conditions; (2) choose representatives to bargain collectively for a contract with their employer; (3) partake in necessary steps with co-workers to ensure the improvement of important working conditions; (4) picket and strike; and (5) choose not to participate in any of the above-mentioned activities. ${ }^{28}$

The NLRB's purpose is to ensure that the rights of employees to organize and decide whether or not to form a union are preserved and are not infringed by any challenge by private sector employers. ${ }^{29}$ Organizationally, the NLRB is allowed to create regional boards to whom the NLRB may delegate its powers, with the NLRB reserving full authority to review the regional boards' decisions. ${ }^{30}$ The NLRB currently has twenty-six regional

The NLB and "The Old NLRB", NAT'L LABOR RELATIONS BD., https://www.nlrb.gov/who-we-are/ourhistory/nlb-and-old-nlrb (last visited Nov. 11, 2016). Shortly after its disbanding, a new board was created, also called the National Labor Relations Board; however, this too would suffer a short life span, as it "ceased to exist for all practical purposes" when the U.S. Supreme Court ruled that the NIRA was unconstitutional in A.L.A. Schechter Poultry Corp. v. United States on May 27, 1935. See Valerie A. Sanchez, A New Look at ADR in New Deal Labor Law Enforcement: The Emergence of a Dispute Processing Continuum Under the Wagner Act, 20 OHIO ST. J. ON DisP. Resol. 621, 645-46 (2005).

25 National Labor Relations Act of 1935, 29 U.S.C. § 153(a) ("The [NLRB] created by this subchapter ... is continued as an agency of the United States .....").

26 "Employee" is defined in the NLRA as "any employee, ... unless this subchapter explicitly states otherwise." See 29 U.S.C.A. § 152(3) (West 2016). Excluded from the class of "employees" is "any individual ... or any individual employed by ... any other person who is not an employer as herein defined." $I d$. The class of employers is then carved out by excluding "any State or political subdivision thereof." Id. at $\$ 152(2)$.

27 National Labor Relations Act, NAT'L LABOR Relations BD., https://www.nlrb.gov/resources/national-labor-relations-act (last visited Nov. 11, 2016).

28 U.S. DEP'T OF LABOR, EMPLOYEE RightS UNDER THE NATIONAL LABOR RELATIONS ACT, https://www.dol.gov/OLMS/regs/compliance/EmployeeRightsPoster11x17_Final.pdf.

29 What We Do, NAT'L LABOR RELATIONS BD., https://www.nlrb.gov/what-we-do (last visited Nov. 1, 2016).

3029 U.S.C.A. $\S 153$ (b) (West 2016) ("The Board is also authorized to delegate to its regional directors its powers under section 159 of this title to determine the unit appropriate for the purpose of collective bargaining, to investigate and provide for hearings, and determine whether a question of representation exists, and to direct an election or take a secret ballot ... and certify the results thereof, except that upon the filing of a request therefor with the Board by any interested person, the Board may review any action of a regional director delegated to him under this paragraph, but such a review shall not, unless specifically ordered by the Board, operate as a stay of any action taken by the regional director."). 
offices available to serve union employees and prospective union employees. $^{31}$

If an employee believes that his or her rights under the NLRA have been violated, he or she may initiate the process of a review by the NLRB by filing a charge against a specific labor organization or an employer. ${ }^{32}$ The NLRB will then review the charge and gather evidence, upon which the findings are reviewed by the applicable Regional Director. ${ }^{33}$ If the NLRB concludes that there is enough evidence to proceed, it will file a complaint against the employee's employer (thus becoming the representative of the employee) and a NLRB Administrative Law Judge will conduct a hearing to determine whether to dismiss the complaint or order the employer to refrain from exercising unfair labor practices. ${ }^{34}$ The NLRB has the power to petition for a temporary injunction to the applicable U.S. District Court and "seek makewhole remedies, such as reinstatement and backpay for discharged workers, and informational remedies, such as the posting of a notice by the employer promising to not violate the law." ${ }^{35}$ If the Board decides to dismiss the charge, the employee may appeal to the Office of Appeals in Washington, D.C. ${ }^{36}$ Additionally, the U.S. Court of Appeals can choose to either enforce, set aside, or remand part or all of a case on an appeal initiated by an employer who has been ruled against by the NLRB. ${ }^{37}$

\section{2. "Employee" under the NLRA}

The determination of who is an "employee" under the NLRA has historically been challenging to courts. ${ }^{38}$ The complexity of this determination was echoed by the U.S. Supreme Court in N.L.R.B. v. Hearst Publishing Inc.: "[f]ew problems in the law have given greater variety of application and conflict in results than [in] cases arising" from the question

31 See Regional Offices, NAT'L LABOR RELATIONS BD., https://www.nlrb.gov/who-weare/regional-offices (last visited Nov. 11, 2016).

32 See Investigate Charges, NAT'L LABOR RELATIONS BD., https://www.nlrb.gov/what-wedo/investigate-charges (last visited Jan. 21, 2017).

33 Id.

34 Id.; The NLRB Process, NAT'L LABOR RELATIONS BD., https://www.nlrb.gov/resources/nlrbprocess (last visited Jan. 21, 2017).

35 Investigate Charges, supra note 32.

36 Id.

37 The NLRB Process, supra note 34.

38 See Lewis L. Maltby \& David C. Yamada, Beyond "Economic Realities": The Case For Amending Federal Employment Discrimination Laws To Include Independent Contractors, 38 B.C. L. REV. 239, 243 (1997) (observing that controversy continues to exist as to the difference between employees and those classified as independent contractors, among other classifications of workers). 
of who is an employee. ${ }^{39}$ The first step in understanding who is an employee under the NLRA begins by reviewing the plain text of the statute, which defines "employee" broadly as "any employee" and states that the definition of an employee "shall not be limited to the employees of a particular employer, unless this subchapter explicitly states otherwise ...." ${ }^{40}$ The Act provides for some examples of who is not an employee, including agricultural laborers and individuals employed "in domestic service of any family or person at his home, or ... by his parent or spouse, or any individual having the status of an independent contractor." 41

This broad definition has created controversy and conflict between courts as to who is actually included in this statutory definition. ${ }^{42}$ Professor Griffin Toronjo Pivateau argued that the omission of a clear definition of an "employee" in the NLRA made the NLRB, and subsequent courts that review the Board's decisions on appeal, rely on tests established by the common law of agency in order to properly make the determination as to who is an employee under the NLRA. ${ }^{43}$ This assertion has support in various decisions by the NLRB and subsequent appeals of its decisions, as well as other scholarly analyses. ${ }^{44}$ The common law principle of agency is expressed in the Restatement of Agency, ${ }^{45}$ which has been expounded by the U.S. Supreme Court in Community for Creative Non-Violence v. Reid into thirteen factors:

1. The hiring party's right to control the manner and means by which the product is accomplished .... [;] 2. The skill required; 3 . The source of the instrumentalities and tools; 4 . The location of the work; 5 . The duration of the relationship between the parties; 6 . Whether the hiring party has the right to assign additional projects to the hired party; 7 . The extent

39 N.L.R.B. v. Hearst Publ'ns, Inc., 322 U.S. 111, 121 (1944) (noting the difficulty in distinguishing from an employer-employee relationship and a relationship arising between an independent contractor and a company).

4029 U.S.C.A. $§ 152(3)$ (West 2016).

41 Id.

42 See, e.g., FedEx Home Delivery v. N.L.R.B., 563 F.3d 492, 496 (D.C. Cir. 2009) (asserting that the notion that a "bright line test" can determine who is an employee is "a long recognized rub"); Smith v. Castaways Family Diner, 453 F.3d 971, 975 (7th Cir. 2006) (stating that the question of who can be considered an employee under the NLRA is "a recurring question"); Willmar Elec. Servs., Inc. v. N.L.R.B. 968 F.2d 1327, 1330-1331 (D.C. Cir. 1992) (finding that "employees" under the NLRA can include paid union organizers); N.L.R.B. v. Henlopen Mfg. Co., 599 F.2d 26, 30 (2d Cir. 1979).

43 Griffin Toronjo Pivateau, Rethinking the Worker Classification Test: Employees, Entrepreneurship, and Empowerment, 34 N. ILL. U. L. REV. 67 (2013).

44 See Mitchell H. Rubinstein, Employees, Employers, and Quasi-Employers: An Analysis of Employees and Employers Who Operate in the Borderland Between an Employer-and-Employee Relationship, 14 U. PA. J. BUS. L. 605, 617 (2012) (finding that most cases analyzing this complex question have a starting point of the "common law right to control" test).

45 David Million, Keeping Hope Alive, 68 WASH. \& LEE L. REV. 369, 371 (2011). 
of the hired party's discretion over when and how long to work; 8 . The method of payment; 9 . The hired party's role in hiring and paying assistants; 10 . Whether the work is part of the regular business of the hiring party; 11 . Whether the hiring party is in business; 12 . The provision of employee benefits; and 13. The tax treatment of the hired party. ${ }^{46}$

These factors were first approved for usage in the courts by the U.S. Supreme Court in Singer Manufacturing Company v. Rahn ${ }^{47}$ and the list is considered to be non-exhaustive. ${ }^{48}$ Professor Mitchell H. Rubinstein of New York Law School analyzed the historical application of these factors by various courts and found that their application in a "mechanistic fashion" was not recommended by courts; however, he found that there was a particular emphasis on the factor of control exerted by the employer on a potential employee. ${ }^{49}$ Professor Rubinstein's view of the factors' application was based on a review of various cases and is well-supported. ${ }^{50}$

Although the factors explained by the Court in Community for Creative Non-Violence were in place, there were still inconsistencies in rulings of who was considered an "employee" for purposes of the NLRA. ${ }^{51}$ Eventually, the U.S. Supreme Court attempted to resolve the conflict in N.L.R.B. v. Town \& Country Electric, Inc. ${ }^{52}$ In Town \& Country, the Court ruled that even prospective employees applying for employment were "employees" and thus entitled to protection under the NLRA. ${ }^{53}$ In making its decision, the Court

46 Cmty. for Creative Non-Violence v. Reid, 490 U.S. 730, $751-52$ (1976). In addition to these factors, a "plaintiff must have received some form of remuneration to establish that he or she was hired." Rubinstein, supra note 44, at 618 (citing Salamon v. Our Lady of Victory Hosp., 514 F.3d 217 (2d Cir. 2008)).

47132 U.S. 518, 523 (1889) (finding that "the relation of master and servant exists whenever the employer retains the right to direct the manner in which the business shall be done, as well as the result to be accomplished, or, in other words, 'not only what shall be done, but how it shall be done.'") (internal citation omitted).

48 See Reid, 490 U.S. at 751-52.

49 Rubinstein, supra note 44, at 618 (finding that "special weight is given to the control of the manner and means by which assigned tasks are completed.").

50 See, e.g., Salamon, 514 F.3d at 226 (holding that the default method used for making the determination of whether an individual should be considered an employee under the NLRA should be the test of common law agency); Nationwide Mutual Ins. Co. v. Darden, 503 U.S. 318 (1992) (finding that the common law standard was appropriate); Eisenberg v. Advance Relocation \& Storage, Inc., 237 F.3d 111, 114 n.1 (2d Cir. 2000); Aymes v. Bonelli, 980 F.2d 857, 862 (2d Cir. 1992); BWI Taxi Mgmt., Inc., N.L.R.B. Case No. 5-RC-16489, 2010 WL 4836874, at*7 (2010) (providing examples of cases within the NLRB that use the common law test).

51 N.L.R.B. v. Town \& Country, 516 U.S. 85, 88 (1995).

52 Id.

53 Id. at 87-88. This decision reversed the ruling of the U.S. Court of Appeals, which held that the definition of "employee" under the Act does not cover "those who work for a company while a union simultaneously pays them to organize the company." The Board found this reasoning well-founded based 
found that the Board's definition of "employee" "“when a servant performs services for another, under the other's control or right of control, and in return for payment" ${ }^{54}$ ), which it used to make its determination in this case, was consistent with the common law test and the agency factors. ${ }^{55}$ Additionally, the Court reasoned that an inclusive definition of an "employee" was in harmony with the NLRA's purposes, including "protecting 'the right of employees to organize for mutual aid without employer interference[ ]" and "encouraging and protecting the collective-bargaining process."

As Professor Rubinstein asserted, the Court in Town \& Country emphasized the control factor of the common law agency factors in its usage of the common law test. ${ }^{57}$ This reliance on the common law agency test, along with the importance of the control factor, within the NLRB's analyses of who is an "employee" was also echoed in N.L.R.B. v. United Insurance Company of America ${ }^{58}$ In United Insurance, the U.S. Supreme Court concluded that, based on Congress' passing of an amendment that excluded employees labeled as an independent contractor from the definition of "employee" under the Act, it was clear that Congress intended for the NLRB to apply the common law agency test in determining whether an individual is an independent contractor or an employee under the NLRA. ${ }^{59}$

Case law supports granting deference towards the NLRA's definition of an "employee" as "any employee," and accepting the U.S. Supreme Court's comprehensive, historic, and literal interpretation of the Act. ${ }^{60}$ Additionally, unless a particular group of workers has been explicitly excluded from the NLRA's definition of an "employee," that particular group is clearly encompassed in the statutory definition. ${ }^{61}$ Courts have examined the issue of who is an "employee" under the Act by using the thirteen factors laid out in Community for Creative Non-Violence ${ }^{62}$ as well as examining the issue with

on Phelps Dodge Corp. v. N.L.R.B.: "statutory word 'employee' included job applications, for otherwise the Act's prohibition of 'discrimination in regard to hire' would 'serve no function'." 313 U.S. 177, 18586 (1941).

54 N.Y. Univ., 332 N.L.R.B. 1205, 1206 (2000).

55 See Town \& Country, 516 U.S. at 94.

56 Id. at 91.

57 Id. at 94.

58 See N.L.R.B. v. United Ins. Co. of Am., 390 U.S. 254, 256-59 (1968) (examining control as a byproduct of the entrepreneurialism of an individual).

59 See id. at 256.

60 See N.Y. Univ., 332 N.L.R.B. 1205 (N.L.R.B. Oct. 31, 2000); N.L.R.B. v. Town \& Country, 516 U.S. 85, 91-95 (1995); Sure-Tan, Inc. v. N.L.R.B., 467 U.S. 883, 891-92 (1984); N.L.R.B v. Hendricks County Rural Elec. Membership Corp., 390 U.S. 170, 185-86 (1981); Phelps Dodge Corp. v. N.L.R.B., 313 U.S. 177, 185-86 (1941).

61 Sure-Tan, 467 U.S. at 883, 891-92.

62 See, e.g., United Ins. Co. of Am., 390 U.S. at 259; Bartels v. Birmingham, 332 U.S. 126, 132, (1947); Dumas v. Gommerman, 865 F.2d 1093, 1105 (6th Cir. 1989); Hilton Int'1 Co. v. N.L.R.B., 690 
an emphasis on the first factor, commonly referred to as the common law control test, as the Court did in the case of Town \& Country. ${ }^{63}$

\section{B. Northwestern University Rulings on Scholarship Athletes}

\section{Region 13 Ruling (2014)}

On March 26, 2014, the Region 13 board of the NLRB ("Regional Board") issued its ruling in Northwestern University (Regional Decision), in which it concluded that scholarship football students were employees under the NLRA based on the common law control test. ${ }^{64}$ The Regional Board's rationale included an in-depth examination of the following factors of the case: (1) the benefit Northwestern received from the services performed by the students; (2) the compensation received by the students as a result of the football-related activities; and (3) the control Northwestern and its employees exerted on the students with regard to their football duties. ${ }^{65}$

The first aspect of the Regional Board's rationale was an examination of the benefit received by Northwestern as a result of the services provided by the scholarship athletes. ${ }^{66}$ It found that, given that the football program at Northwestern generated revenues in the amount of $\$ 235$ million during a nine-year span, Northwestern undoubtedly received an immense benefit from the scholarship student athletes' services. ${ }^{67}$ Aside from the direct financial stream from "ticket sales, television contracts, merchandise sales, and licensing agreements," the Regional Board also noted that the University received an "immeasurable positive impact" from its football team's reputation that directly impacted alumni donations and applicants to the University. ${ }^{68}$

With regard to compensation for the student athletes, the record demonstrated that the scholarships received by the athletes were valued as high as seventy-six thousand dollars per year for each student's tuition, room, board, fees, and books. ${ }^{69}$ Additionally, the Regional Board found that the

F.2d 318, 320 (2d Cir. 1982); N.L.R.B. v. Maine Caterers, Inc., 654 F.2d 131, 133 (1st Cir. 1981), cert. denied, 455 U.S. 940 (1982).

63 See Town \& Country, 516 U.S. at 90-91, 93-95; United Ins. Co. of America, 390 at 256 (examining the proper definitions for an employee within the NLRA); Lancaster Symphony Orchestra, 357 N.L.R.B. 152 (2011); Anne Marie Lofaso, The Vanishing Employee: Putting the Autonomous Dignified Union Worker Back to Work, 5 FIU L. REV. 495 (2010).

64 Nw. Univ., Case No. 13-RC-121359, at *14 (2014).

65 Id. at *14-17.

66 Id. at *14.

67 Id.

68 Id.

69 Id. 
"tender" the athletes were required to sign before receiving the yearly scholarship was essentially an employment contract. ${ }^{70}$ This compensation was directly attributable to the football related-services - and the quality of those services - performed on the field because the head coach, along with the University's athletic department, could "reduce or cancel the player's scholarship for a variety of reasons." 71

In establishing that Northwestern exercised control over the students, the Regional Board detailed the average life of a student athlete at Northwestern to demonstrate the exhaustive control the University exerted on each student. ${ }^{72}$ The Regional Board concluded this based on the various facts, including: that the students devoted up to fifty hours a week on activities for the football program ${ }^{73}$ and that the coaches of the football team mapped out virtually every minute of what the player could and could not do during game days, including what they will wear and what time they will go to sleep. ${ }^{74}$

\section{Appeal to the NLRB (2015)}

Less than one month after the Regional Board's ruling in Northwestern University (Regional Decision), the NLRB reversed the decision in Northwestern University by declining to exert its jurisdiction in the case because it felt that doing so would not be consistent with the purposes of the Act. ${ }^{75}$ In declining jurisdiction, the Board was very careful to clarify that its decision would not serve as an indication as to whether scholarship student athletes were in fact "employees" for purposes of the NLRA. ${ }^{76}$

The Board identified several factors that weighed in favor of its decision to reverse the Regional Board's ruling, including: (1) the nature of the NCAA sports league (in that many of the athletic programs are part of public universities which would not be subject to the NLRB's jurisdiction); (2) the fact that, in the NLRB's mind, the student athletes did not fit into "any analytical framework that the Board ha[d] used in cases involving other types of students or athletes," including student assistants; and (3) the fact that the NCAA had begun to allow universities to give four-year guaranteed scholarships, thus reducing the risk that a student that is unable to play would lose access to scholarships and other aid necessary to fund his or her

70 Id.

71 Id. at $* 15$.

72 Id. at $* 16$.

$73 \quad I d$. at $* 15$.

74 Id. at *15-16.

75 Id. at *3.

76 Id. 
education. ${ }^{77}$ Although the Board declined jurisdiction, they expressly left the door open for a future challenge given different circumstances. ${ }^{78}$

\section{NLRB Decisions Regarding Student Assistants}

The NLRB's decisions regarding whether student assistants, a group that includes those that are graduate and undergraduate students, are employees under the NLRA has taken various twists and turns throughout the last forty years. The Board has gone back-and-forth and has for now seemingly issued a decision in Columbia University that has broad implications for scholarship student athletes everywhere. Prior to understanding these implications and examining exactly how similar student assistants and scholarship student athletes are, it is imperative to understand how the NLRB has historically viewed student assistants and how that view is a fluid source of confusion.

\section{Establishing Precedent: Stanford (1974)}

Stanford ${ }^{79}$ was the second case in two years that the NLRB directly dealt with the issue of considering student assistants as employees under the NLRA ${ }^{80}$ In this case, the NLRB found that research assistants who were also graduate students were not "employees" under the NLRA. ${ }^{81}$ The NLRB's rationale in this decision was that the research assistants were primarily students upon examination of their compensation and work. ${ }^{82}$ Although the students received compensation for their work, the NLRB concluded that it was tied directly towards their education and not necessarily their work product - as would be the case if the students were truly employees. ${ }^{83}$ With respect to the work done by the research assistants, the NLRB found that the work was geared towards obtaining their respective degrees and their performance was not under the control of the university. ${ }^{84}$

$77 \quad I d$. at $* 3-6$.

78 Id. at *6 ("Further, we are declining jurisdiction only in this case involving the football players at Northwestern University; we therefore do not address what the Board's approach might be to a petition for all FBS scholarship football players (or at least those at private colleges and universities).”).

79 Leland Stanford Junior Univ., 214 N.L.R.B. 621 (1974).

80 The first was, Adelphi Univ., 195 N.L.R.B. 639 (1972), finding that graduate researchers and teaching assistants were primarily students.

81 Leland Stanford Junior Univ., 214 N.L.R.B. at 621.

82 Id. at 621-23.

83 Id. at 621.

84 Id. at $622-23$. 


\section{A Departure from Stanford: NLRB Rules that Graduate Assistants Are Employees in New York University (2000)}

In New York University, the NLRB ruled that the graduate assistants employed by New York University ("NYU") were "plainly and literally" employees under the NLRA ${ }^{85}$ - thereby reversing a twenty-six-year-old precedent. ${ }^{86}$ The primary factors the NLRB focused on in making this determination were part of the common law control test: (1) the graduate assistants provided NYU with services that were performed under the control and direction of the university; and (2) the graduate assistants were compensated with financial aid. ${ }^{87}$

NYU had argued that the graduate assistants were not employees for three reasons: (1) the graduate students only spent fifteen percent of their time performing services for the university; ${ }^{88}$ (2) financial aid was not compensation; and (3) the work performed was primarily educational. ${ }^{89}$ In dismissing the first argument, the NLRB stated that although the graduate assistants spent a relatively small amount of their time working (relative to their school commitment), they were "no less 'employees' than part-time" employees. ${ }^{90}$ The Board also found that financial aid was compensation because the students received it for performing services for the university and did not receive any academic credits. ${ }^{91}$ Finally, the Board found that although the graduate students did receive an educational benefit from their work, the work was not a requirement for obtaining their desired degree. ${ }^{92}$

85 N.Y. Univ., 332 N.L.R.B. 1205 (2000).

86 The decision reversed Leland Stanford Junior University. See Brown Univ., 342 N.L.R.B. 483, 483 (2004).

87 N.Y. Univ., 332 N.L.R.B. at 1206.

88 NYU advanced this argument because in Boston Medical Center, where the NLRB ruled that house staff at a hospital were employees under the NLRA, one of the factors that influenced the Board in its ruling was the fact that the staff dedicated roughly eighty percent of its time performing services for the hospital. 330 N.L.R.B. 152 (1999).

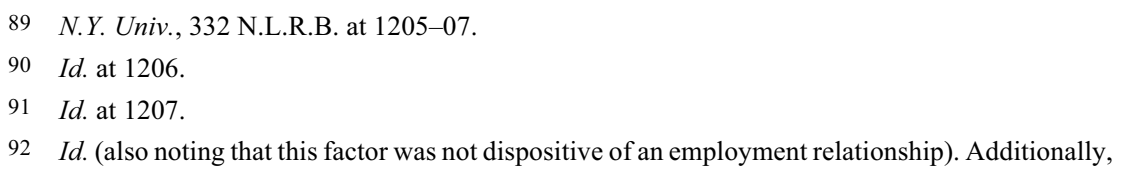
NYU tried to advance the following policy argument against allowing the graduate students to have collective-bargaining rights: NYU argued that allowing them to unionize would "infringe on [NYU]'s academic freedom." Id. Primarily, the university was concerned about what the graduate students would want should they be allowed to collectively bargain. However, the Board was not convinced by this argument, stating that such a concern did not constitute an infringement on academic freedom and that the concern "put the proverbial cart before the horse." Id. at 1208-09. 


\section{Reversion to Stanford: Brown University (2004)}

Unfortunately for graduate assistants, the New York University precedent would not last long. Roughly one year after ruling that graduate assistants were "employees" under the NLRA, the NLRB overruled New York University in its decision in Brown University, thus returning the Board to the Stanford precedent. ${ }^{93}$ Although the facts of the Brown University case were very similar to that of New York University, the Board reasoned that the relationship between the graduate assistants and Brown University ("Brown") was primarily educational, not economic, ${ }^{94}$ and found that the standard in Stanford was more in harmony with the purposes of the NLRA, ${ }^{95}$ as the "imposition of collective bargaining ... would improperly intrude into the educational process and would be inconsistent with the purposes and policies of the Act." 96

\section{The Current Standard: Columbia University (2016)}

Brown University would soon be subject to the same fate as its predecessor, Stanford. Twelve years after the Board overturned New York University, the Board overturned Brown University and established once again that student assistants (this time including graduate, undergraduate, and Ph.D. students) are employees under the NLRA in Columbia University. ${ }^{97}$ Specifically, the Board in Columbia University found that "[w]here student assistants have an employment relationship with their universities under the common law test ... this relationship is sufficient to establish that the student assistant is a Section 2(3) employee for statutory purposes." 98

The Board found that the student assistants met the common law test for employment. ${ }^{99}$ The Board concluded this based on the fact that (1) Columbia University ("Columbia") directed and oversaw the student teaching assistants' activities; (2) the work conducted by the student teaching assistants "advance[d] a key business operation" of Columbia; (3) student teaching assistants were subject to removal if they did not perform their

93 Brown Univ., 342 N.L.R.B. 483, 483 (2004) (holding that the Board will "return to the Board's pre-NYU precedent that graduate student assistants are not statutory employees.").

$94 I d$. at 488 (reasoning that in order for the graduate assistants to earn money they had to be enrolled in the university and the majority of their time was spent working on obtaining their degree).

95 Id. at $487-88$.

96 Id. at 493.

97 Trs. of Columbia Univ., 364 N.L.R.B. 90, at*1 (2016).

$98 I d$. at $* 4$. The Board also noted that a future Board is not required to find that workers are employees in all instances that workers meet the common law test. $I d$.

99 Id. at $* 14-15$. 
duties correctly; and (4) receipt of their financial aid award was conditioned on their work performance. ${ }^{100}$ Similar facts existed for student research assistants, as they were also under the control and direction of their Columbia-employed directors, the university received the benefit of a portion of the grant as revenue from the student research assistant's work, and the students had to perform their duties in order to receive their financial aid. ${ }^{101}$

A theory presented by Columbia against the ruling-which could potentially address any concerns towards classifying scholarship student athletes as "employees" - was that identifying the student assistants as one bargaining unit was inappropriate because it comprised many different groups into one. ${ }^{102}$ According to the university, each of the segments had differences in benefits, compensation, responsibilities, and interests. ${ }^{103}$ The Board disagreed with Columbia's rationale, finding that the collective group of students was an appropriate bargaining unit because they shared a "community of interests." 104

\section{ANALYSIS OF THE NORTHWESTERN UNIVERSITY (REGIONAL DECISION) AND NORTHWESTERN UNIVERSITY DECISIONS}

As discussed above, NLRB case precedent has endorsed a clear common law control test for whether a worker is an "employee" for purposes of the NLRA, which is: "when a servant performs services for another, under the other's control or right of control, and in return for payment." ${ }^{105}$ Using this test as a framework for the examination of whether Northwestern's scholarship student athletes are "employees," it is very clear that they are employees that are covered within the framework of the Act given the amount of control exerted on the scholarship student athletes, the receipt of tuition and other expenses from the University, and the undeniable and beneficial services the student athletes perform for the University. Thus, the Regional

$100 I d$. at $* 15$. The NLRB recalled an instance where a student assistant had his stipend cancelled once he was removed from his position as a teaching assistant. The student received a letter from Columbia stating that "[a]s a result [of your termination], you will no longer receive a salary for this position." The Board viewed this as demonstrating that the stipend was consideration from Columbia for the work student assistants performed on behalf of Columbia University.

101 Id. at *17-18.

102 Specifically, Columbia University was concerned that the bargaining unit grouped undergraduates and graduate students with Ph.D. assistants. Id. at *18.

103 Id.

104 Id. at *19-20. The Board found that the students were all performing "supplemental educational service[s]" and that the differences in compensation did not negate its interpretation in light of the similarities of the students' work done for the university. Id.

105 N.Y. Univ., 332 N.L.R.B. 1205, 1206 (2000); see also N.L.R.B. v. Town \& Country Elec., 516 U.S. 85, 90-91, 93-95 (1995). 
Board's rationale and ruling in Northwestern University (Regional Decision) was the correct application of the common law control test given the current dynamics of collegiate sports, and the NLRB was incorrect in declining to assert its jurisdiction on appeal. ${ }^{106}$

The first part of the common law control test requires that an individual performs a service for another. ${ }^{107}$ The scholarship student athletes participate in football games under the flag of Northwestern on a weekly basis during the college football season. ${ }^{108}$ Depending on the success of the team, this could result in as many as fifteen games during the course of a season. ${ }^{109}$ As a direct result of the scholarship student athletes participating in these football games, Northwestern generated two hundred thirty-five million dollars during a nine-year span. ${ }^{110}$ Thus, it is without a doubt that these scholarship student athletes are providing an extremely beneficial service to their university.

The next prong of the test, that the services are performed "under the other's control or right of control," 111 was also correctly found to be the case in Northwestern University (Regional Decision). ${ }^{112}$ As explained by the Regional Board, the scholarship student athletes are subject to the control of the University through a strict itinerary formulated by the coaching staff (who are paid salaries from the University). ${ }^{113}$ Specifically, the Regional Board found that during training camp: the daily itineraries "set forth, hour by hour, what football related activities the players are to engage in from as early as 5:45 a.m. until 10:30 p.m." players devoted up to sixty hours a week to

106 Many of the facts examined by the Northwestern University (Regional Decision) are still prevalent today, including: the amount of time student athletes dedicate to the sport, the scholarships received, the benefit received by universities from athletic programs, and the amount of control and restrictions university employees place on student athletes.

107 Town \& Country, 516 U.S. at 90-91, 93-95.

108 College football players play a minimum of twelve games during the season, which runs from early September through late November. See 2016 Football Schedule, NU SPORTS, http://www.nusports.com/schedule.aspx?path=football (last visited Nov. 12, 2016); Northwestern Wildcats, ESPN, http://www.espn.com/college-football/team/schedule/_/id/77 (last visited Mar. 1, 2017); Brandon Lilly, College Football Explained, GuARDIAN (Oct. 10, 2012; 9:00 PM), https://www.theguardian.com/sport/blog/2012/oct/10/college-football-explained-ncaa.

109 Depending on the success of the program, a team can play anywhere from one to three additional games on top of their twelve-game regular season, thus stretching the season into December and possibly January. See Chase Goodbread, Urban Meyer Concerned About Length of College Football Season, NFL $\quad$ (Dec. $\quad 31, \quad 2014, \quad 11: 33 \quad$ AM), http://www.nfl.com/news/story/0ap3000000452304/article/urban-meyer-concerned-about-length-ofcollege-football-season.

110 Nw. Univ., Case No. 13-RC-121359, at*14 (2014).

111 N.L.R.B. v. Town \& Country Elec., 516 U.S. 85, 90-91, 93-95 (1995); see also N.Y. Univ., 332 N.L.R.B. 1205,1206 (2000).

112 Nw. Univ., Case No. 13-RC-121359, at*14.

113 Id. 
football-related activities; and that the "location, duration, and manner in which the players carry out their football duties are all within the control of the football coaches." 114 Once the season starts, the control over the student athletes does not let up. ${ }^{115}$ Additionally, throughout the season the coaches are tasked with additional control of the student athletes by monitoring the every action of the student athletes to ensure compliance with team and NCAA guidelines. ${ }^{116}$

The final prong of the common law test for an "employee" is payment in return for the services performed. ${ }^{117}$ As already detailed earlier in this Comment, the financial aid provided to scholarship student athletes as a result of their participation in the football program can end up being as much as seventy-six thousand dollars per year, totaling over three hundred thousand dollars during a student's tenure at Northwestern. ${ }^{118}$ Additionally, players can elect to receive a monthly stipend, which can be spent in any way they choose, in excess of one thousand dollars should they choose to live off campus. ${ }^{119}$ As the Regional Board found, although the University did not treat these payments as taxable income, this was "not dispositive of whether it [was] compensation." "120

Using Northwestern's football program as a basis and examining the Regional Board's rationale, the relationship between these athletes and their university is beyond a simple "student first, athlete second" 121 relationship, as coined by the NCAA and universities nationwide. The scholarship student athletes for all intents and purposes should be considered "employees" under the NLRA given their satisfaction of the common law control test due to the level of control the University and its coaches exert on them, the fact that the scholarship student athletes receive compensation in the form of tuition and other paid expenses from the University, and the fact that the University

$114 I d$.

115 Once the season starts, the students devote around forty to fifty hours per week to football during the season. The football coaches also exercise control over whether a student athlete can: "(1) [choose to] make their living arrangements; (2) apply for outside employment; (3) drive personal vehicles; (4) travel off campus; (5) post items on the Internet; (6) speak to the media; (7) use alcohol and drugs; and (8) engage in gambling." Id. The Regional Board also noted that "[t]he fact that some of these rules are put in place to protect the players and the Employer from running afoul of NCAA rules does not detract from the amount of control the coaches exert over the players' daily lives." Id. at *16.

$116 \mathrm{Id}$.

117 N.L.R.B. v. Town \& Country, 516 U.S. 85, 90-91 (1995); see also N.Y. Univ., 332 N.L.R.B. 1205, 1206 (2000).

118 Nw. Univ., Case No. 13-RC-121359, at*14 (2014).

119 Id.

$120 I d$.

121 Amateurism, supra note 2. 
undeniably receives a beneficial service from the football activities performed by the student athletes.

The NLRB's decision to decline jurisdiction has been met with disdain from several commentators. ${ }^{122}$ In fact, several authors of law review articles and other media personnel found that this non-decision could have potentially created more problems not anticipated by the NLRB. ${ }^{123}$ Professor César F. Rosado Marzán, who has been described as one of the "more analytical criti[cs]" of the decision, ${ }^{124}$ stated that the Northwestern University decision was particularly puzzling because among the Act's purposes is to "equalize bargaining relationships and maintain industrial peace" and found that a decision to not grant the student athletes "employee"-status under the NLRA frustrated that purpose. ${ }^{125}$

Regardless of which test the NLRB were to use in determining whether the student athletes are "employees," ${ }^{126}$ Professor Rosado Marzán argued that student athletes were exactly the type of individuals that the NLRA desires to protect because the student athletes are "providing a valuable service to a more powerful party, and are engaged in disputes over the terms and conditions of their work with that more powerful party, ${ }^{127}$ leading to

122 See, e.g., Edelman, supra note 20; Jake New, NLRB Punts on Northwestern Union, INSIDE HigHER ED. (Aug. 18, 2015),

https://www.insidehighered.com/news/2015/08/18/national-labor-relations-board-declines-assertrolenorthwestern-

football-union; Tyrone Thomas, NLRB Calls Out the Punt Team and Declines Jurisdiction Over Northwestern University Football Players, EMP'T MATTERS (Aug. 18, 2015),

https://www.employmentmattersblog.com/2015/08/nlrb-calls-out-the-punt-team-and-declines-

jurisdiction-over-northwestern-university-football-players/; Sheldon D. Pollack \& Daniel V. Johns, Northwestern Football Players Throw a 'Hail Mary' but the National Labor Relations Board Punts: Struggling to Apply Federal Labor Law to the Academy, 15 VA. SPORTS \& ENT. L.J. 77, 101 (2015); Michael McCann, Breaking Down Implications of NLRB Ruling on Northwestern Players Union, SPORTS ILLUSTRATED (Aug. 17, 2015), http://www.si.com/college-football/2015/08/17/northwestern-footballplayers-union-nlrb-ruling-analysis (concluding that "the National Labor

Relations Board has essentially punted on [the Northwestern University football player unionization] question."); Pasternak, supra note 13.

123 César F. Rosado Marzán, Work, Study, Organize!: Why the Northwestern University Football Players Are Employees Under the National Labor Relations Act, 32 HOFSTRA LAB. \& EMP'T L.J. 301, 318 (2015); Joseph A. Dempewolf, Throwing the Red Flag: A Review of the NLRB's Fumbled Decision Regarding Collegiate Football Players As Employees [Northwestern Univ., 362 N.L.R.B. No. 167 (Aug. 17, 2015)], 55 WASHBuRn L.J. 789 (2016); Michael McCann, Breaking Down Implications of NLRB Ruling on Northwestern Players Union, SPORTS ILlustrated (Aug. 17, 2015), http://www.si.com/college-football/2015/08/17/northwestern-footballplayers-union-nlrb-ruling-analysis.

124 Edelman, supra note 20.

125 Rosado Marzán, supra note 123, at 318.

126 Professor Rosado Marzán cites the following tests: "right of control," "economic realities," and "primary purposes." Id.

127 To demonstrate the unfair balance of power with the relationship between the NCAA and student athletes, Professor Rosado Marzán provides the following issues that student athletes have fought for: "better compensation, health care, protections against catastrophic injury and death, rights to profit 
industrial strife." 128 In his urging that the NLRB reconsider its position, Professor Rosado Marzán stated that by allowing the college athletes to bargain with their university on "the terms and conditions of their duties on the field," the students are effectively bargaining the terms and conditions that could allow them to truly become students of the university. ${ }^{129}$

Joseph Dempewolf articulated several inconsistencies and issues he saw with the Board's decision in Northwestern University. ${ }^{130}$ Among his points, two of the more curious aspects of the Board's decision were: (1) it left the student athletes open to potential retaliation by the University; and (2) the level of deference the NLRB gave to the NCAA was unprecedented. ${ }^{131}$ With respect to the first issue, Dempewolf stressed that the NLRA protects those "employees" who seek the opportunity to collectively bargain against retaliation from their employer. ${ }^{132}$ Now that the student athletes' attempt to unionize has failed, Dempewolf is concerned that they will be subject to retaliation without the protection of the NLRA - as this protection only applies to those considered "employees" under the Act. ${ }^{133}$ Dempewolf also expressed concern with the level of deference the NLRB gave to the NCAA. ${ }^{134}$ The reasons advanced for his assertion that this deference was illadvised were: (1) the spotty record of the NCAA's commitment to the safety of its student athletes, including the lack of enforcement on the NCAA's part of concussion protocols designed to protect the players; (2) the revenues generated by the NCAA has created a conflict of interest between the universities and the student athletes; and (3) the NLRB has never simply deferred to an authoritative body such as the NCAA in similar industries, such as the National Football League and Major League Baseball. ${ }^{135}$

from their names, images, and likenesses, among other rights that they currently do not have because the [NCAA] rules forbid them.” Rosado Marzán, supra note 123, at 302.

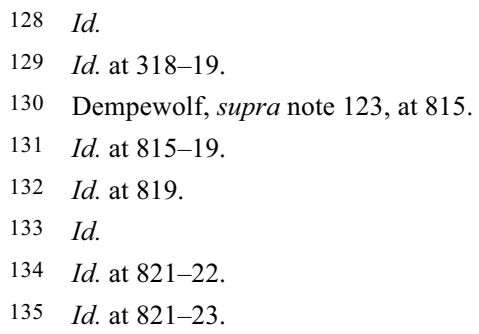




\section{IMPACT OF THE RULING IN COLUMBIA UNIVERSITY ON A RENEWED NORTHWESTERN UNIVERSITY CHALLENGE}

\section{A. Comparing Scholarship Student Athletes with the Student Assistants}

Both the Regional Board and the NLRB found that the scholarship student athletes did not fit into any framework for an employee. ${ }^{136}$ However, both of these cases were decided before Columbia University, where the Board focused on a group of student assistants that included teaching and research assistants ${ }^{137}$ and ruled that they were "employees" under the NLRA. ${ }^{138}$ Columbia University held that: "[w]here student assistants have an employment relationship with their universities under the common law test ... this relationship is sufficient to establish that the student assistant is a Section 2(3) employee for statutory purposes." 139 Given the similarities of the scholarship student athletes in Northwestern University and the student assistants in Columbia University, as will be outlined below, the scholarship student athletes meet and exceed the framework laid out by the Board in its decision in Columbia University and should therefore be considered "employees" once and for all under this framework.

As discussed in Columbia University, with regard to the student assistants, the record demonstrated that Columbia maintained extensive control over the teaching activities of the student assistants, and the students could be removed from their position if they did not perform their duties adequately. ${ }^{140}$ These circumstances ring true with regard to the scholarship student athlete as well: the coaches exerted a level control over the scholarship student athletes that easily exceeds the control that Columbia exercised over its student assistants by virtue of the fact that the coaches were planning essentially every hour of their day. ${ }^{141}$ While Columbia directly supervised its student assistants solely during work hours, the football coaches at Northwestern mapped out the student athletes' days from 6:30 a.m. to $10: 30$ p.m. (at which point they were expected to go to sleep) during training camp. ${ }^{142}$ Additionally, the coaches had control over whether a student athlete could: "(1) make their living arrangement; (2) apply for

136 Nw. Univ., Case No. 13-RC-121359, at *2 (2014), petition dismissed, 362 N.L.R.B. 167 (2015).

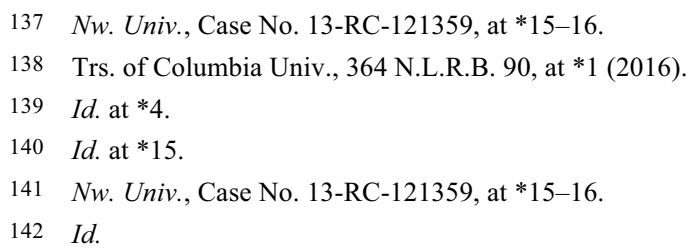


outside employment; (3) drive personal vehicles; (4) travel off campus; (5) post items on the Internet; (6) speak to the media; (7) use alcohol and drugs; and (8) engage in gambling." ${ }^{143}$ In this respect, if student assistants meet the criteria of the "control" portion of the Columbia University framework, then the scholarship student athletes do as well.

The student assistants, like scholarship student athletes, also received compensation in the form of a financial aid award. ${ }^{144}$ In Columbia University, this award was contingent upon the performance of the student assistants' teaching duties and the student assistants would not receive payment if they did not perform their duties. ${ }^{145}$ The scholarship student athletes at Northwestern have strikingly similar circumstances-as they could have their scholarships revoked at any time. ${ }^{146}$ As the Board detailed in Northwestern University (Regional Decision), although the University implemented four-year scholarships,

[T] he fact remains that the Head Coach of the football team, in consultation with the athletic department, can immediately reduce or cancel the players' scholarship for a variety of reasons. Indeed, the scholarship is clearly tied to the player's performance of athletic services as evidence by the fact that the scholarships can be immediately canceled if the player voluntarily withdraws from the team or abused team rules. ${ }^{147}$

Although on its face, a four-year scholarship appears to provide the student athletes with stability and reassurance, the reality behind the scholarship is no different than the compensation received by the student assistants. As with the control-aspect of the Board's analysis in Columbia University, the circumstances of the student assistants and scholarship student athletes' compensation bear an unmistakable resemblance.

Additionally, any concerns regarding the impact of a ruling in favor of scholarship student athletes have already been generally addressed in the Board's decision in Columbia University:

If, historically, the Board had permitted student assistants to engage in collective bargaining, and if actual experience over the years had demonstrated both that collective bargaining rarely proved beneficial to students and that it seriously harmed the ability of private universities to

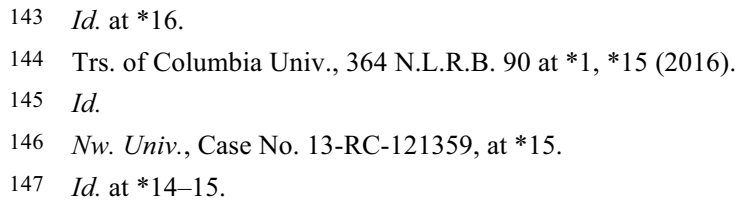


function effectively, then perhaps the Board would have had grounds for deciding that the Act cannot productively be applied in the university setting. ${ }^{148}$

As is the case with scholarship student athletes, neither the Board nor Northwestern (or any university for that matter) has proffered any empirical evidence to justify any legitimate concerns over the result of a potential ruling that scholarship student athletes are employees.

Given the Columbia University standard, a ruling against scholarship student athletes, either by declining jurisdiction or an actual decision, would not be without its share of controversy. In examining the possibility of the NLRB declaring that scholarship student athletes are not "employees" under the NLRA in light of Columbia University, Joseph A. Dempewolf has suggested that such a ruling would potentially create a notion of racial bias. ${ }^{149}$ Dempewolf put forth a recent study that found that nearly forty-six percent of athletes in the NCAA are African-American, ${ }^{150}$ whereas a separate report found that seventy-five percent of all graduate assistants are Caucasian, to support his assertion that a ruling against the student athletes given the status of graduate assistants would "inadvertently create[] a racial divide amongst students who are considered employees."151

\section{B. Issues of a Ruling that Scholarship Student Athletes Are Employees under the NLRA and Possible Solutions}

Among the reasons the NLRB declined to exert jurisdiction, the most intriguing reason was due to the current makeup of the NCAA Football Bowl Subdivision (FBS) model. ${ }^{152}$ The Board noted that only seventeen of the one hundred twenty-five colleges and universities in the FBS are private universities and thus within the Board's jurisdiction. ${ }^{153}$ The student athletes in the state-run institutions would be subject to that particular state's labor laws - including some states that have "specif[ied] by statute that scholarship athletes at state schools are not employees" and that prohibit collective bargaining by public employees. ${ }^{154}$ Additionally, in this instance

148 Trs. of Columbia Univ., 364 N.L.R.B. at *8 (emphasis in original).

149 Dempewolf, supra note 123, at 824.

150 Id. (citing Blacks Now a Majority on Football Teams, ESPN (Dec. 9, 2010), http://sports.espn.go.com/ncaa/news/story?id=5901855).

151 Id. (citing Digest of Education Statistics, NAT'L CTR. FOR EDUC. STATS. (2009), https://nces.ed.gov/programs/digest/d11/tables/dt11_260.asp, (“Caucasians represent the vast majority of graduate assistants with no other race accounting for more than twenty percent.”).

152 Nw. Univ., 362 N.L.R.B. 167, at*5 (2015).

$153 I d$.

154 Id. 
Northwestern is the only team in its conference (the Big Ten) that is a private school. ${ }^{155}$ Thus, even within Northwestern's own conference, the NLRB would not be able to assert its jurisdiction over all of its primary competitors. ${ }^{156}$ All of the above reasons, according to the Board, supported its decision that a ruling in Northwestern University "would not promote stability in labor relations." 157

Despite this self-proclaimed, unresolvable conflict presented by the NLRB, several commentators have examined the Board's decision in Northwestern University as leaving the door open for a collective challenge of all private universities within the NCAA's umbrella and began exploring under what set of circumstances it could potentially work best in. ${ }^{158}$ Of these potential scenarios presented by various commentators, a particular one presented by Marc Edelman, offers the most compelling case.

Edelman interprets the Board's decision in Northwestern University, and its comment that its decision may change if given different circumstances, ${ }^{159}$ to suggest that a bargaining unit comprised of student athletes from a wider range of universities and colleges would be more appropriate for the NLRB. ${ }^{160} \mathrm{He}$ then goes on to suggest that all the private schools that are part of the Atlantic Coast Conference ("ACC"), a conference that competes in various NCAA sports, collectively petition the NLRB to unionize. ${ }^{161}$ These private schools, accounting for nearly half of the teams in the ACC ${ }^{162}$ should theoretically help curb any concerns from the NLRB and present a situation where "lower instability in labor relations ... would emerge from [the NLRB] asserting [its] jurisdiction." ${ }^{163}$

155 Id.

156 Id

157 Id.

158 Edelman, supra note 20; Edelman, supra note 18; Michael McCann, Breaking Down Implications of NLRB Ruling on Northwestern Players Union, SPORTS ILLUSTRATED (Aug. 17, 2015), http://www.si.com/college-football/2015/08/17/northwestern-football-players-union-nlrb-rulinganalysis; Edwin Rios, College Athletes Just Lost a Big Battle. Here's Where the NCAA Pay War Is Headed Next, Mother JONES (Aug. 19, 2015, 5:15 AM), http://www.motherjones.com/northwestern-collegefootball-unionization-loss.

159 Nw. Univ., 362 N.L.R.B. 167, at*1 (2015).

160 Edelman, supra note 20, at 1643 n.91.

161 Id. at 1648.

162 The Atlantic Coast Conference is comprised of fifteen members: Boston College, Clemson University, Duke University, Florid State University, Georgia Institute of Technology, University of Louisville, University of Miami, University of North Carolina at Chapel Hill, North Carolina State University, University of Notre Dame, University of Pittsburg, Syracuse University, University of Virginia, Virginia Tech, and Wake Forest University. Of these fifteen universities, six of them are private (accounting for forty percent). See College Football Teams, ESPN, http://www.espn.com/collegefootball/teams (last visited Apr. 1, 2017).

163 Edelman, supra note 20, at 1643. 
This scenario should potentially bolster any attempt to forge a union with the NLRB, and reduce the likelihood of any possible concerns with "labor instability" promoted with a possible ruling by the Board. Although this does not resolve the entire conflict - as this group of schools would only represent a fraction of the entire NCAA FBS - this would not be the first time the NLRB made a ruling even though it could not assert jurisdiction of an entire industry. A ruling in this scenario would be in line with NLRB precedent, as in its rationale in ruling against Northwestern included the assertion that "in all of our past cases involving professional sports, the Board was able to regulate all, or at least most, of the teams in the relevant league or association []."164

For comparison purposes, there have been several cases in which the NLRB has asserted jurisdiction over cases in which they do not have the authority to assert jurisdiction over the entire organization. For example, in North American Soccer League, the Board exerted jurisdiction in the case even though it could not assert jurisdiction over two of the teams that were located in Canada. ${ }^{165}$ Additionally, the Board has previously adjudicated a case involving referees in the Big East, a conference in the NCAA Division I, even though the Big East at the time of the case was comprised of both private and public universities - as is the case in the current NCAA landscape. ${ }^{166}$

A specific issue related to the public-versus-private institution argument proffered by the NLRB involved the amount of control the NCAA has over key terms of the sport, such as private schools being at the mercy of public schools for the scheduling of games between the two institutions. ${ }^{167}$ Since the NLRB cannot exert jurisdiction over governmental entities such as public schools, the Board would be without recourse should issues of labor violations with respect to scheduling arise. ${ }^{168}$ This issue, although legitimate, should not be controlling over whether the NLRB should have exerted jurisdiction in Northwestern University according to Joseph Dempewolf. ${ }^{169}$

164 Id. (emphasis added).

165 North American Soccer League, 236 N.L.R.B. 1317, 1319, 1321 (1978).

166 Nw. Univ., 362 N.L.R.B. 167, at *5 (2015) (summarizing the Board's findings in that case as follows: "the Board asserted jurisdiction over the conference, based on the theory that it was an independent, private entity created by the member schools; although two of those schools were public institutions, the Board noted that the public schools could not control the conference's operations as they were but two of nine voting members. Thus, aside from the fact that those cases presented different legal issues than are presented here, in both of those cases the Board was able to assert jurisdiction over most of the teams involved.").

167 Dempewolf, supra note 123, at 817.

168 Id.

169 Id. 
Dempewolf cites to Management Training Corporation ${ }^{170}$ as precedent that the NLRB need not have control over a substantial amount of terms in an industry to exert jurisdiction over a particular employer. ${ }^{171}$ This key inquiry for a decision of exerting jurisdiction, according to Management Training Corporation, should be "whether the entity in question meets the employer definition under the NLRA." 172

\section{Why an Affirmative NLRB Decision Would Promote Stability in the NCAA}

Although the scholarship student athletes are "employees" under both the common law control test and the NLRB's framework in Columbia University, the NLRB still has the sole discretion to decline jurisdiction if it determines that a ruling "would not effectuate the purposes of the [NLRA]." 173 This is exactly what the Board decided to do in its review of the Regional Board's decision in Northwestern University. ${ }^{174}$

There is NLRB case precedent that encourages the Board to act in this instance. A variety of NLRB decisions shows that for over forty-five years, the NLRB has exerted its jurisdiction over private universities. ${ }^{175}$ Also, the circumstances surrounding Northwestern University were very similar to those the Board faced in Columbia University and in New York University; there are a countless number of public universities and colleges that would not be subject to the NLRB's jurisdiction and plenty of private universities were not part of the student assistants' petition. ${ }^{176}$ Despite these facts and circumstances, the Board still decided to exercise it jurisdiction and issue a decision.

Additionally, with respect to student assistants, the Board in Columbia University found that issuing a firm ruling would promote the federal labor policy, which is to "encourag[e] the practice and procedure of collective bargaining,' and to protect the workers' 'full freedom' to express a choice for or against collective-bargaining representation." ${ }^{\prime 177}$ Such a ruling in this case

170 Mgmt. Training Corp., 317 N.L.R.B. 1355 (1995).

171 Dempewolf, supra note 123, at 817.

172 Id. at 817-18; Mgmt. Training Corp., 317 N.L.R.B. at 1358.

173 Nw. Univ., 362 N.L.R.B. 167, at*1 (2015).

$174 I d$. Within a total of one hundred twenty-five universities participating in collegiate sports, only seventeen of them are private institutions. See Jeffrey J. Selingo, How Many Colleges and Universities Do We Really Need?, WASH. POST (July 20, 2015), https://www.washingtonpost.com/news/gradepoint/wp/2015/07/20/how-many-colleges-and-universities-do-we-really-need/.

175 Trs. of Columbia Univ., 364 N.L.R.B. 1 , 4 (2016).

176 Nw. Univ., 362 N.L.R.B. at *1.

177 Trs. of Columbia Univ., 364 N.L.R.B. at 6-7. 
would accomplish the same for the scholarship student athletes at Northwestern and potentially student athletes at universities throughout the rest of the country.

Regardless of how the NLRB views the landscape of the NCAA and collegiate football, and the impact of a possible decision in a case like Northwestern University, ${ }^{178}$ such a ruling for scholarship student athletes would actually accomplish the NLRA's purposes and promote stability in the NCAA, which is an institution constantly mired in scandals. For example, one of the more popular scandals in the NCAA involves the issuance of impermissible benefits (money in addition to compensation via tuition) to student athletes, which continuously dominates headlines in sports media. ${ }^{179}$ If student athletes at universities subject to the jurisdiction of the NLRB were allowed to collectively bargain on subjects such as compensation, it would put immense pressure on the NCAA to reconfigure its structure to create an even playing field for all universities and allow for student athletes to be compensated equally.

Some may argue that this would not work because the current playing field is even right now - as no university can directly compensate its players - and the NCAA is still mired in scandals. However, the status quo of players not being compensated outside of tuition, room, and board creates the opportunity for athletic programs to pay its players and potential players, in addition to their other benefits, to gain a competitive advantage because a large majority of student athletes still seek those impermissible benefits. ${ }^{180}$

178 Nw. Univ., 362 N.L.R.B. at *1.

179 See, e.g., A.J. Perez, Stanford Football Player Got Impermissible Benefits; Softball

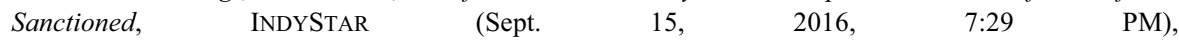
http://www.indystar.com/story/sports/college/2016/09/15/stanford-football-player-got-impermissiblebenefits-softball-sanctioned/90412342/; Zachary Zagger, UNC Denies NCAA High-Level Charges Over Academic Scandal, LAw360 (Aug. 2, 2016, 9:34 PM), http://www.law360.com/articles/824223/uncdenies-ncaa-high-level-charges-over-academic-scandal; NCAA: Baruch gave players over $\$ 255 \mathrm{~K}$ in improper benefits, ESPN (July 10, 2016), http://www.espn.com/womens-collegebasketball/story/_id/16649340/baruch-college-disciplined-giving-players-255k-improper-benefits-fiveyears; Adam Stites, USC's Reggie Bush Scandal is Now the NCAA's Problem, SB NATION (Feb. 7, 2015, 9:34 AM), http://www.sbnation.com/college-football/2015/2/7/7994117/usc-ncaa-todd-mcnair-reggiebush-lawsuit-documents; Ex-Booster: Scandal Will Destroy U. Miami Football, CBS NEWS (Aug. 17, 2011, 2:38 PM), http://www.cbsnews.com/news/ex-booster-scandal-will-destroy-u-miami-football/.

180 The severity and frequency of NCAA violations are so apparent to spectators that one author from Sports Illustrated postulated the perfect way for an individual's favorite program, coach, and student athlete to break the NCAA's rules without getting caught as part of a three-part editorial. See Andy Staples, Cheating for Dummies 2: Your Updated Guide to Smarter NCAA Rule-Breaking, Student-Athlete Editions; Punt, Pass \& Pork, Sports Illustrated (July 5, 2016), http://www.si.com/college-football/2016/07/05/howbreak-ncaa-rules-without-getting-caught; Andy Staples, How Not to Lose Your High-Paying Job in Major College Sports: A Five-Step Guide, SPORTS ILLUSTRATED (Sept. 17, 2015), http://www.si.com/collegefootball/2015/09/17/how-not-lose-your-high-paying-job-college-sports-five-step-guide; Andy Staples, Cheating for Dummies: Your Guide to Smarter NCAA Rule-Breaking (July 5, 2011), http://www.si.com/more-sports/2011/07/05/cheating-dummies. 
This need would be greatly lessened if student athletes everywhere were able to bargain collectively for what they desire-thus creating a potential equal playing field for all universities, both public and private. A ruling in favor of Northwestern's scholarship student athletes could be the first step in an overall reshaping of the structure of the NCAA, to the benefit of both universities and student athletes.

Additionally, as pointed out by Professor Rosado Marzán, the industry of college football is "a multi-billion dollar industry full of labormanagement conflicts deserving of NLRA coverage" that continues to become bigger and bigger. ${ }^{181} \mathrm{He}$ begins his argument by noting that at the inception of the crossover between college athletics and labor, the U.S. Supreme Court stated that: "principles developed for use in the industrial setting cannot be "imposed blindly on the academic world." 182 However, given the sheer size of annual revenues of the sport ${ }^{183}$ and the actual annual salary each player could potentially command, ${ }^{184}$ the college football landscape has become much like other industries that are regulated by the NLRB. ${ }^{185}$

Professor Rosado Marzán states that one of the main purposes of the Act - which is to even the playing field between modest employees in a weaker bargaining position against their more powerful employers-requires that college scholarship student athletes be allowed to exercise the right to organize and collectively bargain, as originally contemplated in the Act. ${ }^{186}$ Additionally, Professor Rosado Marzán points to the countless public and embarrassing issues that the college football industry as a whole has been subjected to, including the high-profile issue of Texas A\&M college football star quarterback Johnny Manziel signing and selling memorabilia against NCAA rules, ${ }^{187}$ and the litigation involving the usage and exploitation of

181 Rosado Marzán, supra note 123, at 319-20.

182 N.L.R.B. v. Yeshiva Univ., 444 U.S. 672, 681 (1980) (citing Syracuse Univ., 204 N.L.R.B. 641,643 (1973)).

183 "In 2010, college football generated over \$2 billion in revenue and \$1.1 billion in profit." Rosado Marzán, supra note 123, at 321 (citing Doug J. Chung, The Dynamic Advertising Effect Of Collegiate Athletics, Harvard Business School Working Paper 5 (Jan. 25, 2013).

184 "A recent Time magazine article reported that college football players could be paid about $\$ 225,000$ by their respective universities." Rosado Marzán, supra note 123, at 321 (citing Sean Gregory, Should This Kid Be Making \$225,047 A Year for Playing College Football?, TimE, Sep. 16, 2013, at 36).

185 Id. at 320.

186 Id.

187 Through the 2013 football season, Johnny Manziel was the subject of a controversy involving reports that he had received compensation in exchange for selling his autograph in violation of NCAA bylaws. This saga dominated the news cycles — raising questions about the NCAA institution as a wholeand concluded in an anticlimactic fashion when Manziel was suspend for the first half of one football game. See Peter Berkes, Johnny Manziel Briefly Suspended, Ending NCAA Autographs Investigation, 
college athletes' likeness in the incredibly popular and profitable, ${ }^{188}$ recently defunct videogame entitled EA Sports NCAA Football, ${ }^{189}$ as evidence that the NCAA is an industry that deserves and needs regulation by the NLRB. ${ }^{190}$

\section{AN ANALYSIS OF RECENT DEVELOPMENTS}

As discussed above, after the NLRB issued its decision in Columbia University several media outlets and newspapers began to discuss the possible ramifications the decision could have on the future of student athletes under the NLRA and the future of college athletics in general. ${ }^{191}$ However, the NLRB added fuel to the debate and did not quash any uncertainty with regard to the status of student athletes when it released two memoranda, one regarding Northwestern's Football Handbook ${ }^{192}$ and the other regarding the NLRB's general counsel's opinion on the subject of

SBNATION (Aug. 28, 2013, 3:10 PM), http://www.sbnation.com/collegefootball/2013/8/28/4668634/johnny-manziel-suspended-texas-a-m; Half-Game Penalty for Johnny Manziel, ESPN (Aug. 29, 2014), http://www.espn.com/college-football/story/_id/9609389/johnnymanziel-texas-aggies-suspended-1st-half-season-opener-rice-owls.

188 In 2013, the video game was estimated to be worth more than $\$ 75,000$ per year for certain teams. Chris Smith, NCAA Football Video Game Is Worth Over \$75,000 Per Year For Top Teams, FORBES (Aug. 22, 2013, 10:47 AM), https://www.forbes.com/sites/chrissmith/2013/08/22/ncaa-footballvideo-game-is-worth-over-75000-per-year-for-top-teams/.

189 Electronic Arts, the video game developer of the popular game NCAA Football, announced in 2013 that they would stop producing the video game due to ongoing litigation from hundreds of former college athletes demanding compensation for the usage of their likeness in the video grams. See Players Are Finally Getting Paid for Old 'NCAA Football' Games. Now Please Make New Ones, SBNATION (Apr. 11, 2016, 2:02 PM), http://www.sbnation.com/college-football/2016/4/11/11408782/ncaa-easports-video-game-settlement-checks-amount; Tony Manfred, EA Sports Cancels its College Football Video Game Amid a Wave of Lawsuits, BUSINESS INSIDER (Sept. 26, 2013, 4:34 PM), http://www.businessinsider.com/ea-sports-cancels-ncaa-football-videogame-2013-9; Darren Rovell, EA Sports Settles with Ex-Players, ESPN (Sept. 26, 2013), http://www.espn.com/collegefootball/story/_id/9728042/ea-sports-stop-producing-college-football-game.

190 See Marzán, supra note 123, at 322, 324-25.

191 Marc Edelman, NLRB Decision to Unionize Columbia Student Workers May Help College Athletes' Union Movement, FORBES (Aug 26, 2016, 2:52 PM), http://www.forbes.com/sites/marcedelman/2016/08/26/nlrb-decision-to-unionize-columbia-studentworkers-may-help-college-athletes-union-movement/\#6ac8d6e05a1a; Scharff, supra note 18; Jared Keller, Graduate Assistants are Officially University Employees. Why Aren't Athletes?, Pacific Standard (Aug. 24, 2016), https://psmag.com/graduate-assistants-are-officially-university-employees-why-arentathletes-8834ed0d8d5f; Lawrence E. Dubé, Will College Athletes' Labor Rights Follow Grad Student Ruling?, BLOOMBERG BNA (Sept. 23, 2016), https://www.bna.com/college-athletes-laborn57982077527/ (citing an interview with Mark J. Neuberger, an employment lawyer that the law firm Foley \& Lardner, Neuberger stated that the NLRB's decision in Columbia University will begin an evolutionary process "of refining the board's approach to various student categories.") Additionally, Neuberger stated that the board "may have to revisit the employee status of student-athletes in a case alleging a single university committed an unfair labor practice" and that "in the right circumstances ... sympathies would line up with the players rather than the universities." Id.

192 KEARNY, supra note 23. 
student athletes. ${ }^{193}$ An analysis of these two memoranda, and their impact on the issue, will be discussed in full below.

\section{A. Northwestern's Football Handbook}

In August 2015, charges alleging unfair labor practices were brought against Northwestern with regard to restrictions the University's Football Handbook ("Handbook") placed on its student athletes, specifically: the student athletes' ability to communicate with media, their usage of social media, and their ability to disclose medical conditions to the public. ${ }^{194}$ Prior to the issuance of an Advice Memorandum from Barry J. Kearney, Associate General Counsel of the NLRB General Counsel's Office ("Advice Memorandum") - and probably in an exercise of an abundance of caution due to the close call the University faced in Northwestern University (Regional Decision) - Northwestern deleted and modified various provisions of the Handbook. ${ }^{195}$ The Advice Memorandum, which analyzed the Handbook under the assumption that the scholarship student athletes were statutory employees and taking into consideration the modifications by Northwestern, ultimately concluded that the Handbook still violated provisions of the Act but ultimately decided not to pursue the complaint because, once again, it would "not effectuate the policies and purposes of the NLRA."196

Some in the labor and employment field viewed the Handbook as a classic example of an employer exercising control over its employees. ${ }^{197}$ The bringing of charges and the conclusions contained in the Advice

193 Richard F. GRIFFIn, JR., OfFICE OF THE GEN. COUNSEL, MEMORANDUM GC-17-01 (Jan. 31, 2017), https://apps.nlrb.gov/link/document.aspx/09031d4582342bfc.

194 Zachary Zagger, Northwestern Football Social Media Limits Unlawful: NLRB, LAw360 (Oct. 11, 2016 5:24 PM), https://www.law360.com/articles/850068/northwestern-football-social-media-limitsunlawful-nlrb; Alexia Elejalde-Ruiz, Northwestern Modifies Handbook to Treat Football Players Like Employees, CHI. TRIB. (October 11, 2016, 4:47 PM), http://www.chicagotribune.com/business/ctnorthwestern-handbook-nlrb-1012-biz-20161011-story.html; Lester Munson, Free to Tweet: Northwestern's Restrictions on Football Players Ruled Unlawful, ESPN (Oct. 10, 2016), http://www.espn.com/espn/otl/story/_id/17765516/nlrb-rules-northwestern-restrictions-unlawful.

195 Previously, the Handbook's social media policy prohibited student athletes from posting material that "could embarrass you, your family, your team, the Athletics Department or Northwestern University." KEARNY, supra note 23. This overly broad restriction was revised by the University to incorporate a prohibition of more specific material, such as sex, drugs, and harassment. With regard to speaking to the press, the Handbook, prior to its modification, did not allow student to speak to members of the press until the University's office of communication arranged for it - this language was essentially removed. Additionally, the original version strictly prohibited student athletes from discussing any medical issues with any third parties. The revision to the rule now allows them to discuss medical issues "generally known and available to the public." Id.

196 Id.

197 Elejalde-Ruiz, supra note 1944. 
Memorandum sent a clear warning to all private universities within the NCAA: review your rules, as they might imply that you view your student athletes as employees. ${ }^{198}$ Although what is contained in a handbook may not be binding on a decision as to whether scholarship student athletes are employees of a given university, it is nonetheless incriminatory and is something that a university would be better off modifying to reduce the perception that it views its student athletes as employees.

\section{B. Memorandum GC 17-01}

Four months after the Advice Memorandum created short-term optimism for those that support the rights of student athletes to unionize, the NLRB would soon release another memorandum that may spell another dent in the armor of the NCAA. As with the Advice Memorandum, another General Counsel of the NLRB, this time Richard J. Griffin, released Memorandum GC-17-01 ("GC-17-01"), which dealt with the "General Counsel's Report on the Statutory Rights of University Faculty and Students in the Unfair Labor Practice Context."199

Griffin stated that FBS football players are "employees" under the NLRA because, as discussed in this Comment, "they perform services for their college and the NCAA, subject to their control, in return for compensation"- thus meeting the common law control test for a statutory employee. ${ }^{200}$ Among Griffin's concerns and reasons for releasing GC-17-01, Griffin stated that he wanted to address the uncertainty the Northwestern University decision left with respect to the lack of potential protection student athletes have from retaliation, including: "advocat[ing] for greater protections against concussive head trauma and unsafe practice methods, reform[ing] NCAA rules so that football players can share in the profit derived from their talents, or self-organiz[ing], regardless of whether the Board ultimately certifies the bargaining unit."

Although GC-17-01 does not change anything legally in the fight to rule that scholarship student athletes are employees, several commentators have declared that this is another crushing blow to the NCAA and private universities. ${ }^{202}$ In fact, as discussed by attorneys at the law firm Arent Fox

198 Id.
199 GRIFFIN, JR., supra note 1933.
200
Id.
201 Id.
202 See Kathy Hoekstra, NLRB Memo Puts College Football Players in Union 'Red Zone,'

202 See Kathy Hoekstra, NLRB Memo Puts College Football Players in Union 'Red Zone,' NLRB General Counsel Asserts that College Football Players Are "Employees", NAT'L L. REV. (Mar. 5, 2017), http://www.natlawreview.com/article/nlrb-general-counsel-asserts-college-football-players-are- 
LLP, it is likely that GC-17-01 could be rescinded later this year because the term for Griffin, an Obama Administration appointee, is set to expire in November and will be replaced by a presumably Republican-friendly individual. ${ }^{203}$

\section{CONCLuSion}

The "decision" by the NLRB to decline jurisdiction in the Northwestern University case was misguided and counter to the NLRB's purpose. The purpose of the NLRB is to ensure that the rights of employees, such as the right to organize and collectively bargain, are preserved and are not infringed by any challenge from private sector employers. ${ }^{204}$ The scholarship student athletes in Northwestern and other private universities are in the prototypical unequal balance of power relationship with their employers, the universities, which the NLRB strives to assist with and balance the playing field. ${ }^{205}$

Despite the finality and ambivalence of the Board's decision in Northwestern University, the NLRB's recent ruling in Columbia University, in which the Board changed its position yet again on whether students assistants (including graduate and undergraduate students) should be considered employees under the NLRA, ${ }^{206}$ has created the opportunity and likelihood that given another chance to make a decision in a Northwestern University-like case, the Board will ultimately declare that scholarship student athletes are "employees" under the NLRA and are thus an appropriate unit for the purposes of collective bargaining.

In examining the primary test the NLRB uses to determine whether a group should be considered a statutory employee, ${ }^{207}$ scholarship student athletes without doubt satisfy the common law test for "employee" because the athletic activities they perform at the control of their coaches are a service to their respective universities, which the university unquestionably receives

employees; Michael L. Stevens, Alexandra M. Romero \& Richard L. Brand, Back in the Game: NLRB General Counsel Says That Scholarship Football Players at Private Universities Are Employees Under the NLRA, LEXOLOGY (Feb. 6, 2017), http://www.lexology.com/library/detail.aspx?g=b97f6c9a-7913423a-9047-30cf23235454; Lester Munson, NLRB Rules Football Players at Private FBS Schools Are Employees, ESPN (Feb. 3, 2017), http://www.espn.com/espn/otl/story/_id/18612851/nlrb-rules-footballplayers-private-fbs-schools-employees; Jon Solomon, NLRB Counsel: Football Players at Private FBS Schools are Employees, CBS SPORTS (Feb. 2, 2017), http://www.cbssports.com/collegefootball/news/nlrb-counsel-football-players-at-private-fbs-schools-are-employees/.

203 Stevens, Romero \& Brand, supra note 2022.

204 What We Do, NAT'L LABOR RELATIONS BD., https://www.nlrb.gov/what-we-do (last visited Nov. 1, 2016).

205 Rosado Marzán, supra note 123 , at 320.

206 Trs. of Columbia Univ., 364 N.L.R.B. 1, 6-7 (2016).

207 See N.Y. Univ., 332 N.L.R.B. 1205, 1206 (2000) (placing an emphasis on the control one has over another when determining whether an individual is an "employee"). 
various benefits from, in exchange for payment in the form of tuition, stipends, room and board, and meal allowances. Additionally, the NLRB should have no trouble classifying scholarship student athletes as "employees" because the group fits into the framework established in Columbia University due to the similarities between student athletes and student assistants, including the relationship the students in both groups have with their university and the strings attached to the compensation each group receives directly from its employer in the form of tuition payments.

In response to the NLRB's concern over the implications of "labor stability" in the NCAA from a potential ruling, ${ }^{208}$ a challenge by a conference such as the ACC, which is comprised of roughly half of private institutions, should help assuage any concerns. NLRB precedent should suggest that the Board may assert its jurisdiction even if this scenario does not present itself. $^{209}$ Additionally, the ruling would promote labor stability due to the sheer size of the industry and because allowing student athletes to collectively bargain for their benefits could reduce the likelihood of universities providing improper benefits to student athletes and being subject to NCAA sanctions.

Until the NLRB has another opportunity to review a case involving scholarship student athletes like those in Northwestern University, student athletes in private universities throughout the country shall remain bound by the NLRB's "decision" thus precluding them from being "employees" under the NLRA. However, in addition to the landmark Columbia University decision, recent developments from the NLRB such as the two memoranda addressed in this Comment show that the future is bright for scholarship student athletes to finally be ruled as "employees."

Although scholarship student athletes have lost the first round of this "David and Goliath" battle, the framework has been laid for the NLRB to force the NCAA to cease its delusion and accept the reality of college

208 Board Declines Jurisdiction, supra note 11, at 6. Specifically, the Board held:

[We have] never asserted jurisdiction, or even been asked to assert jurisdiction, in a case involving scholarship football players or similarly situated individuals, and for the reasons stated above, we decline to do so in this case. Processing a petition for the scholarship players at this single institution under the circumstances presented here would not promote stability in labor relations.

Id. (emphasis added).

209 See, e.g., Nw. Univ., 362 N.L.R.B. 167, at *5 (2015) (discussing a case the NLRB adjudicated involving referees in the Big East conference, which contained both public and private institutions and thus the NLRB could not assert its jurisdiction on the entire conference); Mgmt. Training Corp., 317 N.L.R.B. 1355 (1995) (NLRB stating that although it may not be able to assert its jurisdiction on the entire industry, the key inquiry was whether a particular employer was a statutory employer); North American Soccer League, 236 N.L.R.B. 1317, 1319, 1321 (1978) (case where the Board chose to assert its jurisdiction even though it could not assert jurisdiction on two teams located in a different country). 
athletics: the title "student athlete" is merely a well-disguised misnomer. ${ }^{210}$ But for now, we are left living in the reassuring and satisfying delusion championed by the NCAA and endorsed, albeit an endorsement through inaction, by the NLRB, that student athletes are "students first, athletes second." 211

210 In detailing the history of the term "student athlete," authors Robert A. McCormick and Amy Christian McCormick note that the term began with the NCAA desiring to craft a label for the students to "diminish any tendency to characterize [the student] as "employees." See Robert A. McCormick \& Amy Christian McCormick, The Myth of the Student-Athlete: The College Athlete as Employee, 81 WASH. L. REV. 71, 84 (2006) (citing WALTER BYERS WITH CHARLES HAMMER, UNSPORTSMANLIKE CONDUCT: ExPloiting COLlege ATHLETES 69-70 (1995)). The article recounts a former NCAA executive director's push to address the threat of students being labeled as employees:

We crafted the term student-athlete, and soon it was embedded in all NCAA rules and interpretations as a mandated substitute for such words as players and athletes. We told college publicists to speak of 'college teams,' not football or basketball 'clubs,' a word common to the pros.

Id. The NCAA adopted and mandated the term 'student-athlete' purposely to buttress the notion that such individuals should be considered students rather than employees.

211 Amateurism, supra note 2. 